\title{
Chapter 5 \\ The Implementation of the Landing Obligation in Small-Scale Fisheries of Southern European Union Countries
}

\author{
Sebastian Villasante, Manel Antelo, Maria Christou, Laurence Fauconnet, \\ Katia Frangoudes, Francesc Maynou, Telmo Morato, Cristina Pita, \\ Pablo Pita, Konstantinos I. Stergiou, Celia Teixeira, George Tserpes, \\ and Vassiliki Vassilopoulou
}

\begin{abstract}
In the European Union, discards represent a major source of undocumented mortality, contributing to the overfishing of European fish stocks. However, little attention has been given by the scientific community to discards in the
\end{abstract}

S. Villasante $(\bowtie)$

Faculty of Political and Social Sciences, University of Santiago de Compostela, Santiago de Compostela, Spain

e-mail: sebastian.villasante@usc.es

M. Antelo $\cdot$ P. Pita

Faculty of Economics and Business Administration, University of Santiago de Compostela, Santiago de Compostela, Spain

M. Christou $\cdot$ K. I. Stergiou

Institute of Marine Biological Resources and Inland Waters, Hellenic Centre for Marine

Research, Anavyssos, Greece

Aristotle University of Thessaloniki, Thessaloniki, Greece

L. Fauconnet

Departamento de Oceanografia e Pescas - Okeanos, Instituto do Mar (IMAR), Universidade dos Açores, Horta, Portugal

K. Frangoudes

University of Brest, Ifremer, CNRS, UMR 6308, AMURE, IUEM, Plouzané, France

F. Maynou

Institut de Ciències del Mar, CSIC, Barcelona, Spain

T. Morato

Marine and Environmental Sciences Centre (MARE), Institute of Marine Research (IMAR) and OKEANOS Research Unit, Universidade dos Açores, Horta, Portugal

C. Pita

Department of Environment and Planning \& Centre for Environmental and Marine Studies

(CESAM), University of Aveiro, Aveiro, Portugal

C. Teixeira

MARE - Marine and Environmental Sciences Centre, Faculdade de Ciências, Universidade de Lisboa, Lisbon, Portugal 
European Union's small-scale fisheries (SSF). This is mainly due to the fact that discards are mostly generated by industrial fisheries, while SSFs were generally thought to have lower discard rates than industrial fisheries. A Landing Obligation (LO) is being introduced in European waters with the reform of the Common Fisheries Policy (CFP) (Article 15, EU regulation 1380/2013) to limit/reduce discarding. However, management recommendations are required to support its implementation. The reality and challenges to enforce the LO in SSF are analyzed in this chapter, gathering information from different small-scale fisheries and fishers from the Atlantic Ocean and Mediterranean Sea who were asked about their perceptions toward the LO. The objectives of this chapter are to (a) identify the reasons for discarding and (b) investigate the multiple ecological, economic, social, and institutional drivers which act as a barrier toward the implementation of the LO in SSF. Given the high importance of SSF in the southern countries of Europe, different case studies of SSF from France, Greece, Portugal, and Spain coasts are used to illustrate the reasons for discarding, the impacts of the LO on SSF, and the barriers for its implementation.

Keywords Common Fisheries Policy · Discards · Impacts · Landing Obligation · Small-scale fisheries · Southern Europe

\title{
5.1 Introduction
}

In the European Union (EU), discards represent a major source of undocumented (or poorly documented) mortality, contributing to the overfishing of European fish stocks. Discarding levels in EU fisheries vary between locations, gears, species, and fishing grounds (Uhlmann et al. 2013). However, data collection and estimates of discards for all commercial species in EU waters under the CFP are far from being complete and generally have low precision. This reflects the relatively low intensity of discard sampling and the high variability in amounts of fish discarded, even within a single fishery. The omission and/or poor discard data from stock assessments may also result in underestimation of exploitation rates and can lead to biased assessments and policy recommendations, hampering the achievement of resilient and sustainable fishery resources uses (Aarts and Poos 2009).

The implementation of a Landing Obligation (LO) was one of the key elements of the recent reform of the EU Common Fisheries Policy (CFP) (Regulation (EU) No 1380/2013). A phased LO was formally implemented in January 2015, and by 2019

\author{
G. Tserpes \\ Institute of Marine Biological Resources (IMBR), Hellenic Centre of Marine Research, \\ Anavyssos, Greece \\ V. Vassilopoulou \\ Institute of Marine Biological Resources and Inland Waters, Hellenic Centre for Marine \\ Research, Anavyssos, Greece
}


it will be in force in all EU waters, covering all fisheries that capture commercial species covered by the CFP regulation, including SSF. Landings from EU SSF are worth around $€ 2$ thousand million euros annually, i.e., $25 \%$ of the revenue generated by EU fisheries, and SSF therefore have a high value in the seafood supply chain. Around $80 \%$ of EU fishing boats and more than $40 \%$ of EU fishers $(90,000)$ are engaged in SSF (Macfadyen et al. 2011), emphasizing that SSF is a sector with great social, economic, and cultural importance for coastal communities, especially in southern Europe.

The small-scale fleet has declined by $20 \%$ over the last 10 years, to just over 70,000 vessels. Small-scale vessels are on average between 5 and $7 \mathrm{~m}$ in length, weigh 3GT, and have engines with a power of $34 \mathrm{~kW}$ (Macfadyen et al. 2011). More than $90 \%$ primarily use passive gears (i.e., gears that are not towed or dragged through the water) such as drift and fixed nets, hook and lines, or pots and traps. Despite their importance, for decades, EU fishery policy (e.g., quotas, subsidies, management systems) has focused on large-scale fishing, and there is a lack of knowledge about biological, environmental, socioeconomic, management, and policy aspects of SSF. SSF faces diverse challenges and pressures, not least to establish appropriate governance systems.

However, little research has been done on the impacts of the LO on SSF (Villasante et al. 2015a; Veiga et al. 2016). Therefore, the specific objectives of this chapter are to (i) identify the reasons for discarding among SSF, (ii) determine the factors (ecological, economic, institutional) that act as barriers for the successful implementation of the LO, and (iii) identify the institutional arrangements and/or rules that either inhibit or facilitate an adaptation of the LO.

\subsection{The Status of Discards in Small-Scale Fisheries}

To examine research gaps regarding discards in SSF, we did a systematic literature search to identify relevant scientific papers published up to August 2018 in Scopus, by searching titles, abstracts, and keywords using the following terms: "fisher*" or "fishing"; "discard"”; and "artisan*" or "small-scale" or "traditional" or "subsistence" or "local" or "industrial" or "commercial" or "large." The results obtained show that the topic of discards in SSFs attracted little attention among the scientific community. A total of 1219 papers have been published on the topic of discards from 1950 to August 2018, of which 952 are related to industrial fisheries (78\%) with only 267 papers focused on SSF (21\%) (Fig. 5.1). The review also showed that the little attention paid by the scientific community to discards in SSFs is due to the belief that discard problems were mainly concentrated in industrial fisheries, while SSFs generally have lower discard rates (Villasante et al. 2016a).

Discarding occurs not only due to poor gear selectivity and the capture of unwanted "low value" fish but also due to the mismatch between catch composition and regulatory catch or size limits. Undersize fish may be discarded due to the MLS regulations; over-quota fish can be discarded in a multi-species fishery due to quota 


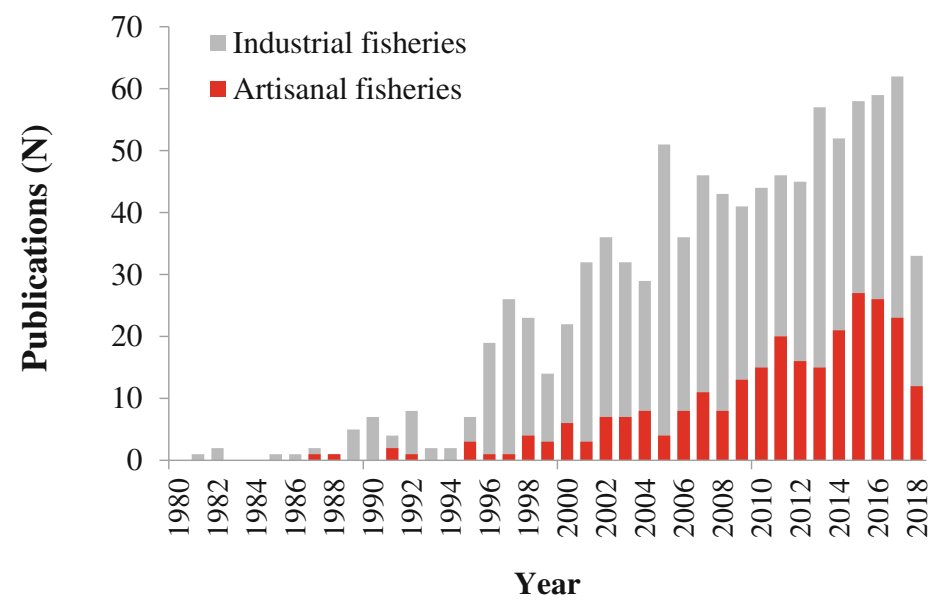

Fig. 5.1 Number of scientific papers published in relation to discards from industrial and artisanal fisheries (1950-2018). (Source: Scopus)

exhaustion of one species, and less valuable size classes of target species may be discarded to make room for more valuable size classes (high grading). Even if high grading has been legally forbidden, it is still known to occur on a regular basis. All these issues are reported to be present in EU SSF (Villasante et al. 2016a, 2016b, 2016c). These different reasons for discarding impact heavily on the willingness to comply with rules and regulations.

\subsection{Impacts of the Landing Obligation in Small-Scale Fisheries}

The term SSF implies small vessel size and, sometimes, low levels of technology and capital investment per fisher. For the purposes of the European Maritime and Fisheries Fund (Regulation (CE) No 508/2014, "small-scale coastal fishing" was formally defined as fishing done by vessels of an overall length $<12 \mathrm{~m}$ and not using towed gear. SSF are thus typically "artisanal" and coastal, using small boats, targeting multiple species using traditional gears.

To investigate the impact of the LO in SSF, we will focus on the impact of this measure on selected SSF in the EU - in France, Greece, Portugal, and Spain. We will describe these fisheries, their discards, the reasons for discarding, impact of the LO, factors that act as barriers for the successful implementation of the LO, and the institutional arrangements and rules that inhibit or facilitate the adaptation to the LO. 


\subsubsection{France}

\section{Small-Scale Fisheries in the British Channel, Celtic Sea, and Bay of Biscay}

In France, the small-scale fleet is not legally defined. The number of hours spent at sea is the main criterion to classify the vessels rather than length or use of passive gears. For the purpose of this chapter, only vessels $<12 \mathrm{~m}$ of the length operating within territorial waters $(12 \mathrm{~nm})$ in the British Channel, Celtic Sea, and Bay of Biscay are taken into account. See Table 5.1 for the characteristics of this fleet and the main species landed. The majority of the target species in the Atlantic Coast/ Ocean are subject to Total Allowable Catch (TAC) regulations.

Interviews were done with small-scale fishers operating in the English Channel, Celtic Sea, and Bay of Biscay as part of the EU DiscardLess project (http://www. discardless.eu). All French fishers interviewed perceived the LO negatively not only because they felt that it will reduce their activity and increase expenditure on their boats but that it also shows that decisions were made at the top level without taking in account the good management practices implemented by the fisheries committees or POs over the last 15 years (van Hoof et al., this volume). That is, French smallscale fishers feel that European decision-makers satisfy claims and interests of lobbies (conservationists, aquaculture) rather those of fishers (De Vos et al. 2016).

According to interviewed fishers, the main reasons for discarding are regulatory, such as quotas, forbidden species, etc. Low market prices and high grading are also given as reasons for discarding (Table 5.2). Damaged fish was also mentioned by netters or long-liners. It is probably that because SSF implemented a quota system later than the larger fleet, and the fact that they have smaller amounts of quota, these fishers discard more. New fishers, who do not own quotas, have to fish under an open national quota system, managed by the national fisheries administration, and because these quotas are rapidly filled, they are obliged to discard all fishes over quota. Young fisherwomen using nets as the main fishing gear say: "As soon as the national quota closes, all fish caught under the quotas system are discarded. We are not members of the local PO, and we cannot access more quotas." In some regions, POs manage quotas collectively; thus, the quota can be swapped among fishers, with the result that it is easier for them to avoid high discard rates.

Undersize fish, when mentioned, did not really represent a constraint to French small-scale fishers. They all say that the gears they use are more selective than those used by the industrial fleet. But they cannot avoid all undersize fish as "there is not a fishing gear which doesn't catch undersize fishes." For those using handline or traps, unwanted fish can easily be returned alive to the sea. The "lack of a good price" for some species, for example, European plaice (Pleuronectes platessa) in the Eastern Channel and European hake (Merluccius merluccius) or Atlantic horse mackerel (Trachurus trachurus) in the Bay of Biscay, is given as another reason for discarding. For fishers, discarding species without commercial value is not perceived as discards. It is the same when it comes to high grading practiced by fishers to 
Table 5.1 Case studies characterization

\begin{tabular}{|c|c|c|c|c|c|}
\hline Case study & Country & Fishing fleet & Gear used & $\begin{array}{l}\text { Main species } \\
\text { landed }\end{array}$ & $\begin{array}{l}\text { Rules and } \\
\text { regulations }\end{array}$ \\
\hline $\begin{array}{l}\text { SSF in the } \\
\text { British } \\
\text { Channel, } \\
\text { Celtic Sea, } \\
\text { and Bay of } \\
\text { Biscay }\end{array}$ & France & $\begin{array}{l}\text { Vessels less } \\
\text { than } 12 \mathrm{~m} \\
\text { operating } \\
\text { mainly within } \\
\text { territorial } \\
\text { waters }(12 \mathrm{~nm}) \\
\text { using mainly } \\
\text { passive gear }\end{array}$ & $\begin{array}{l}\text { Gillnets, tram- } \\
\text { mel nets, long- } \\
\text { lines, } \\
\text { handlines, nets, } \\
\text { pots and traps, } \\
\text { some SSF ves- } \\
\text { sels using } \\
\text { dredges or } \\
\text { trawls }\end{array}$ & $\begin{array}{l}\text { Common sole, } \\
\text { European sea } \\
\text { bass, pollack, } \\
\text { and monkfish; } \\
\text { total landings } \\
80,000 \text { tons } \\
\text { (in 2013) }\end{array}$ & $\begin{array}{l}\text { Most target } \\
\text { species subject } \\
\text { to TAC and } \\
\text { MLS }\end{array}$ \\
\hline $\begin{array}{l}\text { SSF in the } \\
\text { Thermaikos } \\
\text { Gulf }\end{array}$ & Greece & $\begin{array}{l}\text { Polyvalent pas- } \\
\text { sive gears }\end{array}$ & $\begin{array}{l}\text { Nets, pots, } \\
\text { longlines, traps }\end{array}$ & $\begin{array}{l}\text { Lands a wide } \\
\text { array of spe- } \\
\text { cies, the most } \\
\text { important } \\
\text { being hake, } \\
\text { common cuttle- } \\
\text { fish, mullets, } \\
\text { annular } \\
\text { seabream, sad- } \\
\text { dled seabream, } \\
\text { common octo- } \\
\text { pus, common } \\
\text { pandora, and } \\
\text { scorpionfish; } \\
\text { accounted for } \\
18,152 \text { tons } \\
\text { (in 2016) }\end{array}$ & $\begin{array}{l}\text { Most target } \\
\text { species have } \\
\text { minimum } \\
\text { landing size } \\
\text { (MLS). Plus } \\
\text { spatial restric- } \\
\text { tions and tem- } \\
\text { poral restric- } \\
\text { tions (e.g., } \\
\text { vessels } \\
\text { targeting hake } \\
\text { and exceeding } \\
\text { the limit of } \\
>20 \% \text { of land- } \\
\text { ings are not } \\
\text { authorized to } \\
\text { fish in } \\
\text { February) }\end{array}$ \\
\hline $\begin{array}{l}\text { SSF in } \\
\text { Catalonia }\end{array}$ & Spain & $\begin{array}{l}\text { Polyvalent pas- } \\
\text { sive gears } \\
\text { operating } \\
\text { within } 6 \mathrm{~nm}\end{array}$ & $\begin{array}{l}\text { Trammel nets, } \\
\text { gillnets, boat } \\
\text { seines, pots for } \\
\text { octopus, and } \\
\text { longline }\end{array}$ & $\begin{array}{l}\text { Lands over } \\
200 \text { species, the } \\
\text { most important } \\
\text { being demersal } \\
\text { species (cuttle- } \\
\text { fish, hake, pan- } \\
\text { dora, sole, } \\
\text { golden } \\
\text { seabream), } \\
\text { sand-eel, octo- } \\
\text { pus, and } \\
\text { bonito. Aver- } \\
\text { age landings of } \\
3000 \text { ton/year }\end{array}$ & $\begin{array}{l}\text { Some species } \\
\text { subject to } \\
\text { MLS (e.g., } \\
\text { hake, sole, } \\
\text { Sparidae, } \\
\text { octopus). } \\
\text { Technical lim- } \\
\text { itations to the } \\
\text { size of fishing } \\
\text { gear (e.g., } \\
\text { maximum } \\
\text { length of nets; } \\
\text { maximum } \\
\text { number of } \\
\text { hooks; maxi- } \\
\text { mum number } \\
\text { of traps) }\end{array}$ \\
\hline $\begin{array}{l}\text { SSF in } \\
\text { Galicia }\end{array}$ & Spain & $\begin{array}{l}\text { Vessels less } \\
\text { than } 12 \mathrm{~m} \\
\text { operating } \\
\text { mainly within }\end{array}$ & Gillnet & $\begin{array}{l}\text { Hake, horse } \\
\text { mackerel, } \\
\text { mackerel, } \\
\text { pouting, } \\
\text { surmullet. }\end{array}$ & $\begin{array}{l}\text { Most target } \\
\text { species subject } \\
\text { to TAC, MLS, } \\
\text { and fishing } \\
\text { effort }\end{array}$ \\
\hline
\end{tabular}


Table 5.1 (continued)

\begin{tabular}{|c|c|c|c|c|c|}
\hline Case study & Country & Fishing fleet & Gear used & $\begin{array}{l}\text { Main species } \\
\text { landed }\end{array}$ & $\begin{array}{l}\text { Rules and } \\
\text { regulations }\end{array}$ \\
\hline & & $\begin{array}{l}6 \mathrm{~nm} \text { using } \\
\text { passive gear }\end{array}$ & & $\begin{array}{l}\text { Average daily } \\
\text { catch of } \\
3000 \mathrm{~kg} \\
\text { (in 2018) }\end{array}$ & \\
\hline $\begin{array}{l}\text { Deepwater } \\
\text { hook-and- } \\
\text { line fishery } \\
\text { in the } \\
\text { Azores }\end{array}$ & Portugal & Deepwater & $\begin{array}{l}\text { Bottom long- } \\
\text { lines, handlines }\end{array}$ & $\begin{array}{l}\text { Blackspot } \\
\text { seabream, } \\
\text { European } \\
\text { conger, } \\
\text { Forkbeard, sil- } \\
\text { ver } \\
\text { scabbardfish, } \\
\text { bluemouth } \\
\text { rockfish, } \\
\text { wreckfish. } \\
\text { Total landings } \\
\text { of } 4070 \text { t } \\
\text { (in } 2014 \text { ), 15- } \\
21 \text { M€ between } \\
2010 \text { and } 2017\end{array}$ & $\begin{array}{l}\text { Target and } \\
\text { secondary } \\
\text { species subject } \\
\text { to TAC (e.g., } \\
\text { blackspot } \\
\text { seabream, } \\
\text { alfonsinos). } \\
\text { Deepwater } \\
\text { sharks subject } \\
\text { to TAC zero. } \\
\text { MLS for sev- } \\
\text { eral species, } \\
\text { minimum } \\
\text { hook sizes, } \\
\text { area and tem- } \\
\text { poral closures, } \\
\text { and bans on } \\
\text { the use of spe- } \\
\text { cific gear }\end{array}$ \\
\hline Beach seine & Portugal & Purse seine & $\begin{array}{l}\text { Trawling net to } \\
\text { the beach; } \\
\text { small fishery } \\
\text { consisting of } \\
\text { solely } 143 \text { ves- } \\
\text { sels in the } \\
\text { entire country }\end{array}$ & $\begin{array}{l}\text { Small pelagic } \\
\text { fish such as } \\
\text { mackerel, } \\
\text { Atlantic horse } \\
\text { mackerel, and } \\
\text { sardine }\end{array}$ & $\begin{array}{l}\text { Horse mack- } \\
\text { erel } \\
\text { (Trachurus } \\
\text { spp.) subject } \\
\text { to TAC }\end{array}$ \\
\hline
\end{tabular}

Note: SSF, small-scale fisheries; MLS, minimum landing size; nm, nautical miles; TAC, Total Allowable Catch

obtain better prices. Only the biggest individuals are landed; all the others, including those having legal size, are discarded.

The impacts of the LO will be different for fishers using different gears. Netters think that in some seasons they will have high rates of discards (e.g., Atlantic horse mackerel), that they will have to come to the harbor to land before returning back to their fishing areas. Handling and sorting fish will take longer, and they do not know if crew members will do it. For them, the need to employ one more crew member to deal with longer handling times means less income for the crew. All fishers want to know who will pay the different taxes related to auctions, dealing with trash, etc. Netters and long-liners consider that the $\mathrm{LO}$ will have a negative economic impact on their activity. But for the more selective handliners, the $\mathrm{LO}$ was felt to have little economic impact. 
Table 5.2 Reasons for discarding and barriers to implementing the Landings Obligation (LO)

\begin{tabular}{|c|c|c|c|c|c|}
\hline \multirow[b]{2}{*}{ Case study } & \multirow[b]{2}{*}{ Country } & \multirow{2}{*}{$\begin{array}{l}\text { Main reasons } \\
\text { for discarding }\end{array}$} & \multicolumn{3}{|c|}{ Barriers to the implementation of the LO } \\
\hline & & & Ecological & Economic & Institutional \\
\hline $\begin{array}{l}\text { SSF in the } \\
\text { British } \\
\text { Channel, } \\
\text { Celtic Sea, } \\
\text { and Bay of } \\
\text { Biscay }\end{array}$ & France & $\begin{array}{l}\text { Mainly regu- } \\
\text { lations } \\
\text { (quotas, MLS, } \\
\text { and forbidden } \\
\text { species). Also, } \\
\text { low market } \\
\text { value, lack of } \\
\text { commercial } \\
\text { value/market, } \\
\text { high grading, } \\
\text { and damaged } \\
\text { catch }\end{array}$ & $\begin{array}{l}\text { Mix fisheries, } \\
\text { in some sea- } \\
\text { son's abun- } \\
\text { dance of some } \\
\text { species are not } \\
\text { easy to avoid. } \\
\text { Few vessels } \\
\text { located in } \\
\text { estuary areas } \\
\text { deal with } \\
\text { undersize fish }\end{array}$ & $\begin{array}{l}\text { The LO will } \\
\text { increase opera- } \\
\text { tion costs for } \\
\text { netters and } \\
\text { long-liners } \\
\text { (more trips to } \\
\text { land all catch, } \\
\text { increase in crew } \\
\text { to deal with } \\
\text { extra work). } \\
\text { Worries about } \\
\text { who will pay for } \\
\text { taxes related to } \\
\text { the auction, } \\
\text { trash, etc. }\end{array}$ & $\begin{array}{l}\text { Most target } \\
\text { species subject } \\
\text { to quota and } \\
\text { many small- } \\
\text { scale fishers } \\
\text { operate under } \\
\text { the national } \\
\text { open quota } \\
\text { system, which } \\
\text { ends fast }\end{array}$ \\
\hline \multirow[t]{2}{*}{$\begin{array}{l}\text { SSF in the } \\
\text { Thermaikos } \\
\text { Gulf }\end{array}$} & \multirow[t]{2}{*}{ Greece } & \multirow[t]{2}{*}{$\begin{array}{l}\text { Low market } \\
\text { value of the } \\
\text { landings, } \\
\text { damaged } \\
\text { catch, } \\
\text { mishandling } \\
\text { on board, } \\
\text { undersize fish, } \\
\text { small catch }\end{array}$} & \multirow[t]{2}{*}{$\begin{array}{l}\text { Many factors, } \\
\text { mostly caused } \\
\text { by the nature } \\
\text { of the Greek } \\
\text { SSF (multi- } \\
\text { fleet and multi- } \\
\text { species). } \\
\text { Recent data } \\
\text { show that dis- } \\
\text { cards have } \\
\text { risen and are } \\
\text { dominated by } \\
\text { alien species }\end{array}$} & $\begin{array}{l}\text { Economic } \\
\text { incentives seem } \\
\text { to contribute to } \\
\text { discarding prac- } \\
\text { tices; high local } \\
\text { market demand } \\
\text { for fish contrib- } \\
\text { utes to the regu- } \\
\text { lar selling of } \\
\text { undersized fish } \\
\text { in the black } \\
\text { market }\end{array}$ & $\begin{array}{l}\text { Loose enforce- } \\
\text { ment; lack of } \\
\text { spatial moni- } \\
\text { toring system } \\
\text { for vessels } \\
<12 \mathrm{~m} \text { (the } \\
\text { majority of SSF } \\
\text { fleet). } \\
\text { Unknown } \\
\text { number of rec- } \\
\text { reational ves- } \\
\text { sels hardens the } \\
\text { role of fisheries } \\
\text { managers }\end{array}$ \\
\hline & & & & $\begin{array}{l}\text { Fishers do not } \\
\text { perceive an } \\
\text { increase in } \\
\text { operation costs } \\
\text { due to the LO } \\
\text { because they } \\
\text { have little } \\
\text { discards }\end{array}$ & $\begin{array}{l}\text { Fishers oppose } \\
\text { the LO because } \\
\text { it will decrease } \\
\text { their catch. } \\
\text { There is the } \\
\text { need to } \\
\text { decrease the } \\
\text { MLS for some } \\
\text { species to avoid } \\
\text { discards }\end{array}$ \\
\hline $\begin{array}{l}\text { SSF in } \\
\text { Catalonia }\end{array}$ & Spain & $\begin{array}{l}\text { Damaged } \\
\text { catch; low } \\
\text { market value }\end{array}$ & $\begin{array}{l}\text { Largely mixed } \\
\text { fisheries with } \\
\text { relatively } \\
\text { small quanti- } \\
\text { ties of discards } \\
\text { of regulated } \\
\text { species; very }\end{array}$ & $\begin{array}{l}\text { Increased cost } \\
\text { of sorting; inex- } \\
\text { istence of eco- } \\
\text { nomic outlet for } \\
\text { unwanted } \\
\text { catches brought } \\
\text { to land }\end{array}$ & $\begin{array}{l}\text { Loose monitor- } \\
\text { ing, control, } \\
\text { and enforce- } \\
\text { ment capacity } \\
\text { by the fisheries } \\
\text { administration; } \\
\text { lack of }\end{array}$ \\
\hline
\end{tabular}


Table 5.2 (continued)

\begin{tabular}{|c|c|c|c|c|c|}
\hline \multirow[b]{2}{*}{ Case study } & \multirow[b]{2}{*}{ Country } & \multirow{2}{*}{$\begin{array}{l}\text { Main reasons } \\
\text { for discarding }\end{array}$} & \multicolumn{3}{|c|}{ Barriers to the implementation of the LO } \\
\hline & & & Ecological & Economic & Institutional \\
\hline & & & $\begin{array}{l}\text { difficult to } \\
\text { optimize oper- } \\
\text { ations to } \\
\text { completely } \\
\text { avoid } \\
\text { unwanted } \\
\text { catches }\end{array}$ & & $\begin{array}{l}\text { incentives for } \\
\text { compliance }\end{array}$ \\
\hline $\begin{array}{l}\text { SSF in } \\
\text { Galicia }\end{array}$ & Spain & $\begin{array}{l}\text { Lack of quotas } \\
\text { for harvested } \\
\text { commercial } \\
\text { species }\end{array}$ & $\begin{array}{l}\text { Largely mixed } \\
\text { fisheries with } \\
\text { relatively } \\
\text { small quanti- } \\
\text { ties of discards } \\
\text { of regulated } \\
\text { species; very } \\
\text { difficult to } \\
\text { optimize oper- } \\
\text { ations to } \\
\text { completely } \\
\text { avoid } \\
\text { unwanted } \\
\text { catch }\end{array}$ & $\begin{array}{l}\text { The hold space } \\
\text { on board is cur- } \\
\text { rently opti- } \\
\text { mized, and it } \\
\text { would not be } \\
\text { possible to } \\
\text { expand the hold } \\
\text { space without } \\
\text { affecting the } \\
\text { navigability of } \\
\text { the fishing ves- } \\
\text { sels. Small-scale } \\
\text { fishing vessels } \\
\text { hold their } \\
\text { catches on } \\
\text { board in boxes } \\
\text { classified by } \\
\text { species and size, } \\
\text { and the potential } \\
\text { increase on their } \\
\text { number would } \\
\text { increase insecu- } \\
\text { rity of the } \\
\text { vessels }\end{array}$ & $\begin{array}{l}\text { Fishers } \\
\text { strongly } \\
\text { oppose the LO } \\
\text { and the manda- } \\
\text { tory measure to } \\
\text { annotate all } \\
\text { catches in the } \\
\text { electronic log- } \\
\text { book, because } \\
\text { it will be very } \\
\text { difficult and } \\
\text { impractical } \\
\text { during the fish- } \\
\text { ing activities }\end{array}$ \\
\hline $\begin{array}{l}\text { Deepwater } \\
\text { hook-and- } \\
\text { line fishery } \\
\text { in the } \\
\text { Azores }\end{array}$ & Portugal & $\begin{array}{l}\text { Undersize fish } \\
\text { (<MLS), } \\
\text { quota in the } \\
\text { case of } \\
\text { "alfonsinos," } \\
\text { low market } \\
\text { value, dam- } \\
\text { aged catch }\end{array}$ & $\begin{array}{l}\text { Difficult to } \\
\text { avoid } \\
\text { unwanted } \\
\text { catch due to } \\
\text { mixed } \\
\text { resources, } \\
\text { especially } \\
\text { juveniles of } \\
\text { blackspot } \\
\text { seabream; } \\
\text { fishers per- } \\
\text { ceived high } \\
\text { abundance of } \\
\text { deepwater } \\
\text { sharks }\end{array}$ & $\begin{array}{l}\text { Fishers strongly } \\
\text { oppose that } \\
\text { unwanted } \\
\text { undersize catch } \\
\text { cannot be sold } \\
\text { for direct human } \\
\text { consumption; } \\
\text { Representatives } \\
\text { of fish auctions } \\
\text { concerned about } \\
\text { the economic } \\
\text { costs of } \\
\text { collecting and } \\
\text { dealing with the } \\
\text { unwanted catch }\end{array}$ & $\begin{array}{l}\text { Fishers } \\
\text { strongly } \\
\text { oppose that } \\
\text { catch will count } \\
\text { against quota; } \\
\text { limiting quota } \\
\text { for } \\
\text { "alfonsinos" } \\
\text { and TAC zero } \\
\text { for deepwater } \\
\text { sharks could } \\
\text { prematurely } \\
\text { choke the } \\
\text { fishery }\end{array}$ \\
\hline
\end{tabular}


Table 5.2 (continued)

\begin{tabular}{l|l|l|l|l|l}
\hline & \multirow{3}{*}{ Case study } & Country & $\begin{array}{l}\text { Main reasons } \\
\text { for discarding }\end{array}$ & \multicolumn{3}{|l|}{\begin{tabular}{l} 
Barriers to the implementation of the LO \\
\cline { 3 - 5 } Beach seine
\end{tabular}} & Portugal & $\begin{array}{l}\text { Endersize fish } \\
\text { (<MLS), low } \\
\text { market value }\end{array}$ & $\begin{array}{l}\text { Difficult to } \\
\text { implement the } \\
\text { LO due to } \\
\text { fishery being } \\
\text { carried out on } \\
\text { the beach }\end{array}$ & $\begin{array}{l}\text { Fishers strongly } \\
\text { oppose the fact } \\
\text { that catches of } \\
\text { juvenile horse } \\
\text { mackerel } \\
\text { (Trachurus } \\
\text { spp.) cannot be } \\
\text { sold for human } \\
\text { consumption }\end{array}$ & $\begin{array}{l}\text { Fishery carried } \\
\text { out in areas of } \\
\text { great ecological } \\
\text { sensitivity } \\
\text { (nursery areas, } \\
\text { spawning } \\
\text { zones, and/or } \\
\text { growing areas) } \\
\text { and undersize } \\
\text { fish constitute } \\
\text { an important } \\
\text { part of the } \\
\text { catch, but these } \\
\text { can survive }\end{array}$ \\
\hline
\end{tabular}

Note: SSF, small-scale fisheries; MLS, minimum landing size; LO, Landing Obligation

It was felt that the ecosystem will also likely be negatively impacted by the LO because discards returned to the sea are often eaten by birds, other fish, mammals, or benthic scavengers (Depestele et al., this volume). Small-scale fishers wonder what will happen to the ecosystem if discarding practices are ended. They also prefer to continue discarding as usual rather than supporting the aquaculture sector which they perceive is bound to benefit from the implementation of the LO.

For the moment, SSF avoids unwanted catches, especially undersize fishes, by changing fishing areas. Their main concern is the avoidance of seasonal species like mackerels (Scomber spp.) for which they have little or no quota at all. Choke species are the most important constraint because there is always the risk of the fishery to choke, rendering a continuation of operation impossible. Until now, the LO has not been fully implemented, with exemptions having been implemented in all regional seas, but discards are still not landed nor registered officially.

\subsubsection{Greece}

\section{Small-Scale Fisheries in the Thermaikos Gulf}

SSF accounts for the majority of SSF vessels operating in Greek waters (94\%) with a fleet numbering 12,762 vessels in 2014. They are active along the extensive Greek coastline, using polyvalent passive gears and catching a multitude of species (Stergiou et al. 2002; Gonçalves et al. 2007; Tzanatos et al. 2007; Brodersen et al. 2016), and the SSF métiers exhibit significant spatiotemporal variations in catch composition (Tzanatos et al. 2007; Palialexis and Vassilopoulou 2012a, b; 
Table 5.1). Landings are channeled to the market through short supply chains, or directly to restaurants, and sold at an average value of $9 € \cdot \mathrm{kg}^{-1}$. However, landings per vessel as well as income per fisher are generally very low, and each business has low invested capital.

The Greek SSFs are mostly family-owned vessels with one or two people on board, sometimes the husband and wife together. Based on the Data Collection Framework in 2014, this is the largest fishing fleet in European waters, with a steady decrease since 2008, following the general trend in the overall Greek fleet. This segment had a combined gross tonnage of 24.8 thousand GT and a total power of 238.3 thousand kW (STECF 2016).

SSFs are characterized by their multi-gear nature and the targeting of multiple species, with Sepia officinalis, Mullus surmuletus, Diplodus annularis, Oblada melanura, Octopus vulgaris, Pagellus erythrinus, and Scorpaena porcus being landed in high numbers (Stergiou et al. 2002; Gonçalves et al. 2007; Tzanatos et al. 2007; Brodersen et al. 2016) and the SSF metiers exhibit significant spatiotemporal variations in the catch composition (Tzanatos et al. 2007; Palialexis and Vassilopoulou 2012a, b).

In relation to discarding practices, SSF in Greece documents relatively low discarding, with estimates $\sim 10 \%$ of the total catch (Tzanatos et al. 2007; Vassilopoulou et al. 2007). More recent data show that discards have risen (17\% of the catch in 2014-2016, compared to 7.5\% of the catch in 2004-2006) and have been dominated by alien species catches: Siganus luridus - which is commercial in some regions - represented $18 \%$ of discards in weight, while three more alien species (Siganus rivulatus, Stephanolepsis diaspros, Balistes capriscus) have also been documented in a SSF in the Saronikos Gulf (Brodersen et al. 2016).

SSF discards are a result of (i) low commercial value of the landings (e.g., Atlantic lizardfish (Synodus saurus); (ii) fishing practices, i.e., damage to individuals before being brought on board (e.g., European hake); (iii) mishandling on board; (iv) the catch of undersize individuals for species under MLS regimes (e.g., annular seabream (Diplodus annularis); and (v) fish having commercial value but not caught in adequate numbers to be sold (Tzanatos et al. 2007; Gonçalves et al. 2007) (Table 5.2). Other factors such as soaking time, depth of the fishing operations, and the mesh used affect considerably the discard numbers in the trammel net fisheries of the Ionian Sea (Vassilopoulou, unpublished data). In Table 5.1 more information is given on the studies dedicated to the investigation of discard practices of SSF in Greece. They all showed that the overall discarded fraction from SSF is considered as far from being negligible.

There are many factors that act as barriers for the successful implementation of the LO, mostly caused by the nature of the Greek SSF (i.e., different gear used with different species being targeted simultaneously) (Table 5.2). Economic incentives to not discard result in undersized fish being sold regularly on the black market (Damalas and Vassilopoulou 2013).

Interviews with small-scale fishers operating in the Thermaikos Gulf were done in 2015 and 2017 as part of two H2020 projects (MINOUW http://minouw-project.eu 
and DiscardLess). Small-scale fishers in the Thermaikos Gulf said that they never heard about the LO (Christou et al. 2017; Maynou et al. 2017; Fitzpatrick et al. 2017). But as soon as it was explained to them what the LO means, all of them declared to be against it. The rule is perceived as an additional threat for their activity. Small-scale fishers operating in the area say that they are currently in competition with dolphins which constantly destroy their fishing gear (nets) and damage captured fish. They said that dolphins leave little fish in the nets. "If we want to bring fish home, we have to watch our nets; therefore, we stay on the spot." To avoid nets being destroyed due to the presence of the dolphins, fishers never set their nets for several hours. Sometimes soaking time is less than an hour, and fishers of this region have problems earning a living. Within this short time of operation, discards are very low.

Fishers did not know that the LO is already implemented in Greece and had never heard about the ongoing exemptions already granted to them. For them, the main reason for discarding is regulatory and principally the MLS. The other reasons are damaged fish and lack of market prices for some species. They considered that the discarded quantities are low, and they would not have problems to land them if they had to do so. Nowadays, unwanted catches are often landed for human consumption. For example, undersized fish may be offered as a present to clients, to family members and friends, especially when practicing direct sales. Species used to make fish soups, or undersize fish appreciated by the local market (e.g., surmullet Mullus surmuletus) are often given as gifts.

They do not have any problem moving to another fishing area when the quantity of MLS individuals is high because they stay near the nets during the fishing operation "to chase dolphins attacking their gear." If catches contain a lot of small fish, they turn to other fishing grounds. They do not face the same problem when they use pots because unwanted catches remain alive, and as soon as they are put on board, they are released into the sea. They think that live individuals have a high survival rate as soon as they are back into the water. In this way, small-scale fishers think that the LO is not a problem compared to the threat represented by dolphins. For them, the daily struggle against dolphins makes LO a softer constraint. LO doesn't really impact their activity due to their low rates of discards. It is observed that this latter finding contradicts their first negative vision of the LO.

According to fishers, the LO will impact more on trawlers, which generate more discards. For SSF fishers it is a good thing that these boats will have to reduce discards. These two métiers do not operate in the same areas, and little competition for space occurs. But both fleets are targeting the same species, and during the months that trawlers are operating (trawling activity is forbidden in territorial waters between June and the end of September), SSF fishers have problems selling their catch at a good price.

When asked whether they record discards, fishers respond that until the end of 2017 "nobody asked them to record them." And if somebody tells them to do so, they will not comply because they "don't want to complicate their life by adding more administrative tasks." From the interviews, it appears that small-scale fishers of the Thermaikos Gulf are against the LO by principle, but an analysis of their 
discourse demonstrates the opposite. This is due to the fact that such a rule will have little impact on their activities. In the case of effective implementation, they can easily adapt to the LO. The gears that fishers use are among the most selective, and they do not think that they will need to make more effort under the LO (Table 5.2).

The current conditions of SSF in the Thermaikos Gulf may be different from other areas in Greece, but in terms of discards, it seems to be similar to the results of other studies undertaken in that country. Yet, it is crucial to investigate discard levels specific for each métier and quantify the discards problem among the whole SSF sector, using robust indices (Stergiou et al. 2007). The low discards generated by Mediterranean fisheries (Tsagarakis et al. 2014) and also by other fisheries (including areas under a quota system) should prompt authorities to claim a specific exemption at the EU level, as SSF is an important activity for coastal communities and provides income and employment for local populations in areas with few alternative economic activities (Pita et al. 2010), particularly in small, isolated islands. The ongoing financial recession in Greece has further hardened the socioeconomic state of these fisheries. Thus, it is important to safeguard the sector and maintain the social and economic sustainability of the coastal communities.

\subsubsection{Portugal}

Two examples are provided for the impact of the LO in the Portuguese SSF sector: the beach seine fisheries in mainland Portugal, an ancient activity registered in the National Archive of Intangible Cultural Heritage (e.g., in Costa da Caparica beach seine fishery; Diário da República, 2nd series, $\mathrm{N}^{\circ}$ 34, of 16 February 2017), and the deepwater hook-and-line fisheries in the Azores islands.

\subsubsection{The Beach Seine Fishery}

The beach seine fishery is an ancient commercial fishing activity on the Portuguese coast, with reports dating as far back as the early fifteenth century (Franca and Costa 1979; Martins et al. 2000). Nowadays, the beach seine fleet is composed of 143 vessels, distributed along the Portuguese mainland coast, mainly on the northwest coast (European Commission 2018) (Table 5.1). Each vessel employs $\sim 12$ people, 5 working on board the vessel, and 7 working on land. This is a seasonal fishery, typically occurring from March to November. The main target species of the fishery are small pelagic fish such as Atlantic chub mackerel (Scomber colias), Atlantic horse mackerel, and European pilchard (Sardina pilchardus) (Gaspar and Pereira 2014). In Portugal, official fishing statistics landings are presented by fleet component 
(divided into trawling, purse seine, and multi-gear); therefore, it is not possible to know the proportion of landings (in volume and value) by the beach seine fishery.

The beach seine fishery operates in a coastal zone of great ecological sensitivity, as this fishing activity occurs in nursery areas, spawning zones, and/or growing areas for many species of high economic interest. As a consequence, juveniles constitute an important fraction of captures, which commercialization is not allowed by law, as individuals are $<$ MLS, and are thus discarded (Jorge et al. 2002). In addition to capture large numbers of juveniles, this fishing technique is not selective and also captures a wide variety of bycatch species (Faltas 1997; Lamberth et al. 1997; Cabral et al. 2003), despite having seasonally target species (Fagundes et al. 2007). The low commercial value of bycatches and legal constraints results in bycatches not being traded and mostly discarded (Cabral et al. 2003). In this fishery, the LO was implemented on January 1, 2015, and applies to catch of horse mackerels (Trachurus spp.) and blue whiting (Micromesistius poutassou).

\subsubsection{The Deep-water Hook-and-Line Fishery in Azores}

The Azores is a Portuguese oceanic archipelago in the North Atlantic Ocean, with a one million $\mathrm{km}^{2}$ exclusive economic zone (EEZ), no continental shelf and great depths, with an important demersal fishing around the island slopes and the many seamounts present in the area (Silva and Pinho 2007; Morato et al. 2008). The bottom hook-and-line fishery is the most important fishery in the region, employing about $60 \%$ of all professional fishers in the archipelago (Carvalho et al. 2011). This fishery is mostly small-scale, with $92 \%$ of the vessels $<12 \mathrm{~m}(\mathrm{~N}=478$ in 2016) (Table 5.1). Two main fishing gears are used: (i) bottom longlines targeting mainly deep-sea demersal fishes, such as blackspot seabream (Pagellus bogaraveo), alfonsinos (Beryx spp.), or blackbelly rosefish (Helicolenus dactylopterus), or deeper species such as common mora (Mora mora), and (ii) handline targeting mostly blackspot seabream and wreckfish (Polyprion americanus). Both gears operate all year round. The bottom longline and handline fishery is by far the most valuable in terms of landed value, with an annual landed value varying from 15 to 21 million $€$ for the period 2010-2017, around 58\% of all landed value in the Azores (SREA, http:// estatistica.azores.gov.pt).

Unreported catch for this fishery was estimated to amount to $830 \mathrm{t}$ per year on average over the period 2000-2014, i.e., 10.3\% of the total catch (Pham et al. 2013). Around half (47\%) of this unreported catch is used as bait, kept for crew consumption, or offered, while the remaining was discarded at sea $\left(447 \mathrm{t} \cdot \mathrm{year}^{-1}\right.$ ) (Fauconnet et al. in press).

Discard practices are believed to be similar between handlines and bottom longlines. Observer data suggest that the catch of individuals smaller than the MLS is the main cause for discarding in this fishery, followed by low market value (Canha 2013). About 90 species are regularly discarded by this fishery, $40 \%$ 
of which due to low commercial value (Canha 2013). However, $61 \%$ of the discards can be attributed to six species of commercially important fish, such as silver scabbardfish (Lepidopus caudatus), European conger (Conger conger), blackbelly rosefish, splendid alfonsino (B. splendens), blackspot seabream, and thornback ray (Raja clavata). At least ten species of deepwater sharks are occasionally caught by this fishery. Even if limited, this bycatch is of concern since many deepwater sharks such as Deania spp., Centrophorus spp., Etmopterus spp., Centroscymnus spp., and kitefin shark (Dalatias licha) are listed in the IUCN red list of endangered species. Due to their vulnerability, the EU has set their TAC to zero in 2010 (EC Reg. N $^{\circ}$ 1359/2008). Since then, discard of those species has been compulsory. Deepwater sharks accounted for $8 \%$ of the discards of the fishery over the period 2010-2014 (Fauconnet et al. 2016).

The implementation of the LO in Azorean demersal fisheries will only take place from January 2019 onward. Several factors were identified, in semi-structured interviews and meeting with stakeholders, as part of the DiscardLess project, to potentially act as barriers for the successful implementation of the LO in the Azores (Table 5.2).

\subsubsection{Spain}

Two cases from Spain illustrate the complexities of the implementation of the LO in different regions of Spain: the case of SSF in Catalonia (NW Mediterranean) and the gillnet fishery in Galicia (NW Atlantic).

\subsubsection{Small-Scale Fisheries in Catalonia}

SSF in Catalonia is carried out by a relatively high number of fishing units (365 out of a fleet of 727 vessels in 2016) operating from 32 fishing harbors. Landings of the SSF fleet oscillate between 1800 and $3800 \mathrm{t} \cdot \mathrm{year}^{-1}$ in recent years (average $2960 \mathrm{t} \cdot \mathrm{year}^{-1}$ for the period 2000-2016), with a corresponding value of landings around 15 million $€$ (Table 5.1). This fisheries production corresponds to ca. $10 \%$ of the production/landings in Catalonia but employs ca. 50\% of the fishing fleet and $25 \%$ of the labor/fishers. The fleet operates in coastal waters, typically within 6 miles of the coast, uses a multitude of gears, and lands over 200 species, the most important being demersal species and sand eels (Gymnammodytes spp.), common octopus (Octopus vulgaris), and Atlantic bonito (Sarda sarda). Refer to Table 5.1 for detailed information about the fleet, gear and main species landed. In general, the commercial catches of each individual vessel are very low $\left(20-50 \mathrm{~kg} \cdot \mathrm{day}^{-1}\right)$ but of high value, with ex-vessel prices of the target species oscillating between 10 and $20 € \cdot \mathrm{kg}^{-1}$. 
Compared to other segments of the fleet, SSF is highly selective, and the amount of discards is relatively low. The fractions of the catch that are discarded are usually noncommercial species, such as epibenthic invertebrates, or damaged fish. Commercial species that could be otherwise sold are discarded when they are damaged due to scavengers preying on the catch. This problem is particularly acute for set net fishing gear (trammel nets and longlines). Undersize fish are usually not discarded but sold on the black market. Field studies carried out in the MINOUW project show that the amount of catches below legal size is generally low, but for certain species and certain gear deployments, the proportion of catches that will fall under the remit of the Landing Obligation can be high. Trammel nets employing inner panels of 40-60 mm mesh can produce a relatively high proportion of undersize European seabass (Dicentrarchus labrax), Sand steenbras (Lithognathus mormyrus), blackspot seabream (Pagellus bogaraveo), or common sole (Solea solea). In the case of the blackspot seabream, its large legal size $(33 \mathrm{~cm}$ TL) results in all catches from all fishing gears studied being undersize. Several barriers for the implementation of the LO have been identified such as low quantities of discards, the lack of capacity to monitor SSF by the regional administration, and increase costs of sorting, among others (Table 5.2).

\subsubsection{The Gillnet Fishery in Galicia}

Fishing is a major contributor to gross domestic product in Galicia (an autonomous community in northwestern Spain), the main fishing region in Spain (Villasante 2012). The artisanal/SSF fleet is comprised mainly of small vessels (on average $6 \mathrm{~m}$ long), fishing with a great variety of passive gears, the so-called artes menores (traps, hooks and lines, gill and trammel nets, and small seines), and exploiting a diverse range of species, most of which are subjected to TACs.

The fleet using gillnets comprises 1000 fishing vessels, operating in a multispecific SSF, mainly harvesting European hake, pouting (Trisopterus luscus), horse mackerels, and surmullet at depths of 30-140 m and up to 8-10 miles from the coast. Based on results from interviews started in 2015 and updated until 2018, the reasons for discarding are the precautionary closure and the full closure of the fishery due to the full harvest of the TAC (Villasante et al. 2016a, b).

Recently, Villasante et al. (2015b) estimated the total removals of fisheries catches (including IUU catches, subsistence catches, and discards for commercial and recreational fisheries) for the 1950-2010 period. The authors demonstrated that the discard rate for SSFs ranges between 5-18\% depending on the type of commercial species harvested. However, the authors also found that the discard rate for some sedentary resources (e.g., goose barnacle (Pollicipes pollicipes) $74 \%$ and razor clams Ensis spp. 49\%) can be significantly higher than for other SSFs.

However, the species under TAC and quota regulations present high discard rates which ranged between 0 and $-50 \%$ (European hake, mackerels) and/or 50-200\% 
(horse mackerels). Catches of horse mackerels and mackerels are highly variable due to migratory movements from Portuguese to Galician waters and can sometimes lead to high discard rates. Harvesting of immature individuals was reported to be very low or nonexistent for all species caught by this fishery (Villasante et al. 2015b, 2016c).

Regarding the compliance to the LO, the expert's opinion and the participatory consultation made with the small-scale fisheries sector show that changing the fisheries management system based on the TAC regulation would be the most important reason to comply with the LO (Villasante et al. 2016a, b) (Table 5.2).

\subsection{Conclusion}

Despite the increased recognition of SSFs, there is a still need to ensure that policymakers receive robust scientific data about such fisheries on which to base decisions and thus ensure coherent policy. Our results show that only $21 \%$ of 1219 papers that have been published until 2018 focused on the discard problem in SSF.

Key SSFs from around Europe selected to investigate the reasons for discarding, impact, and barriers to implementing the LO illustrate that discard rates vary greatly from fishery to fishery and species to species. However, the main reasons fishers discard are relatively similar from fishery to fishery and are mostly due to regulations (mainly TACs, quotas, and MLS), low market value of some catch components, capture of noncommercial species, high grading, and damaged catch.

Small-scale fishers perceive that it will be difficult to comply with the LO and could identify ecological, economic, and institutional barriers to the implementation of the LO. From an ecological perspective, most fishers are of the opinion that resources are largely mixed, and unwanted catch is very difficult to avoid. For example, the fact that the beach seine fishery in Portugal is carried out in areas of great ecological sensitivity, such as nursery areas, results in the capture of large numbers of juveniles. From an institutional perspective, the lack of monitoring, control, and enforcement capacity by fisheries jurisdictions, combined with lack of incentives for compliance, are critical barriers perceived by fishers for the implementation of the LO in all case studies. Plus, some fishers identified that the implementation of the LO requires the adoption of more selective gear technology (Galicia and Azores). Azores fishers think they are already using one of the most selective gear in European fisheries and as such that the LO should not apply to them.

From an economic perspective, fishers state that the LO will increase the operational costs of fishing activities. They strongly oppose the fact that unwanted undersize catch cannot be sold for human consumption and that this catch will count against their quota. In general, the potential socioeconomic impacts of the LO could be high for SSF. For example, it is estimated that the future yield (catches) under the LO in Galicia (Spain) would be only 50\% of catches expected in the absence of the LO, regardless of the total volume of quotas allocated to the fleet. 
Acknowledgment The authors acknowledge the financial support from the European COST Action "Ocean Governance for Sustainability - challenges, options and the role of science" and by the ICES Science Fund Project "Social Transformations of Marine Social-Ecological Systems", and MINOUW (Grant Agreement 634495). C. Pita acknowledges FCT/MEC national funds and FEDER co-funding, within the PT2020 partnership Agreement and Compete 2020, for the financial support to CESAM (Grant no UID/AMB/50017/2013). C.M. Teixeira had the support of the Fundação para a Ciência e a Tecnologia (FCT) (Pest-OE/MAR/UI0199/2011); and C.M. Teixeira and C. Pita were supported by the Research Project "LESSisMORE - LESS discards and LESS fishing effort for BETTER efficiency on the small-scale fisheries" (Ref. "LISBOA-010145-FEDER-028179"), support by the FEDER Funds through the COMPETE 2020, by the PIDDAC through FCT/MCTES. TM thanks the support from the European Union's Horizon 2020 research and innovation project DiscardLess (Grant Agreement No 633680), the Fundação para a Ciência e Tecnologia (FCT) strategic project UID/MAR/04292/2013 granted to MARE. He is also supported by the Program Investigador FCT (IF/01194/2013/CP1199/CT0002).

\section{References}

Aarts, G., \& Poos, J. (2009). Comprehensive discard reconstruction and abundance estimation using flexible selectivity functions. ICES Journal of Marine Science, 4, 763-771.

Brodersen, M.M., Haralabous, J., Chalari, Dictyopoulos, C., Dogrammatzi, K., Vassilopoulou, V. (2016). Preliminary comparative study of trammel net fisheries in the Saronikos Gulf a decade apart 16th Panhellenic Conference of Ichthyologists, Kavala, pp. 129-132.

Cabral, H., Duque, J., Costa, M.J. (2003). Discards of the beach seine fishery in the central coast of Portugal. Fisheries Research, 63(1), 63-71. https://doi.org/10.1016/S0165-7836(03)00004-3.

Canha, A. (2013). Caracterização das rejeições na pescaria de demersais nos Açores. Master thesis dissertation, University of the Azores, pp 76.

Carvalho, N., Edwards-Jones, G., Isidro E. (2011). Defining scale in fisheries: small versus largescale fishing operations in the Azores. Fisheries Research, 109, 360-369.

Christou, M., Haralabous, J., Stergiou, K.I., Damalas, D., Maravelias, C.D. (2017). An evaluation of socioeconomic factors that influence fishers' discard behaviour in the Greek bottom trawl fishery. Fisheries Research, 195, 105-115.

Damalas, D., \& Vassilopoulou, V. (2013). Slack regulation compliance in the Mediterranean fisheries: a paradigm from the Greek Aegean Sea demersal fishery, modelling discard ogives. Fisheries Management and Ecology, 20, 21-33.

De Vos, B.I., Döring, R., Aranda, M., Buisman, F.C., Frangoudes K., Goti L., et al. (2016). New modes of fisheries governance: Implementation of the landing obligation in four European countries. Marine Policy, 64, 1-8.

Depestele, J., Feekings, J., Reid, D., Cook, R., Gascuel, D., Girardin, R., et al. (this volume). The impact of fisheries discards on scavengers in the sea. In S.S. Uhlmann, C. Ulrich, S.J. Kennelly (Eds.), The European Landing Obligation - Reducing discards in complex, multi-species and multi-jurisdictional fisheries. Cham: Springer.

EU [European Commission]. (2018). Fleet register on the NET 2018. Data provided by MS at 01/06/2018. Build of 13/06/2018 http://ec.europa.eu/fisheries/fleet/index.cfm?method=Search. SearchAdvanced\&country. Accessed 13 June 2018.

Fagundes, L., Tomás, A., Casarini, L., Bueno, E., Lopes, G., Machado, D., et al. (2007) A pesca de arrasto-de-praianailha de São Vincente, São Paulo, Brasil. Série Relatórios Técnicos $\mathrm{N}^{\circ} 29$.

Faltas, S.N. (1997). Analysis of beach seine catch from Abu Qir Bay (Egypt). Bulletin of the National Institute of Oceanography and Fisheries, 23, 69-82.

Fauconnet, L., Pham, C., Canha, A., Afonso, P., Vandeperre, F., Machete, M., et al. (2016). Estimating total fisheries discards in an oceanic archipelago of the NE Atlantic. 7th World Fisheries Congress, Busan, South Korea, 23-27th May 2016. 
Fauconnet, L., Pham, C., Canha, A., Afonso, P., Diogo, H., Machete, M., Silva, M.A., Vandeperre, F., Morato, T. (in press) An overview of fisheries discards in the Azores. Fisheries Research

Fitzpatrick, M., Quetglas, T., Frangoudes, K., Triantaphyllidis, G., Nielsen, K. (2017). DiscardLess policy brief No 2: year 2 of the landing obligation: key issues in Mediterranean fisheries. https:// doi.org/10.5281/zenodo.573666. Accessed 25 July 2018.

Franca, M., \& Costa, F. (1979) Nota sobre as xávegas da Costa da Caparica e Fonte da Telha. Boletín Instituto Nacional de Investigación das Pescas, 1, 37-69.

Gaspar, M., \& Pereira, F. (2014). Pequena pesca na costa continental portuguesa: caracterização sócio-económica, descrição da actividade e identificação de problemas. Instituto Português do Mar e da Atmosfera. pp 268.

Gonçalves, J., Stergiou, K., Hernando, J., Puente, E., Moutopoulos, D., Arregi, L., et al. (2007). Discards from experimental trammel nets in southern European small-scale fisheries. Fisheries Research, 88, 5-14.

Jorge, I, Siborro, S., Sobral, M. (2002). Contribuição para o conhecimento da pescaria da xávega da zona centro. Relatórios Científicos e Técnicos Instituto de Investigação das Pescas e do Mar, $85,1-22$.

Lamberth, S., Sauer, W., Mann, B., Brouwer, S., Clark, B., Erasmus, C. (1997). The status of the South African beach-seine and gill-net fisheries. South African Journal of Marine Science, 18, 195-202.

Macfadyen, G., Salz, P., Cappell, R. (2011). Characteristics of small-scale coastal fisheries in Europe. Policy Department: Structural and Cohesion Policies, European Parliament, Fisheries pp 162 .

Martins, R., Carneiro, M., Rebordão, F., Sobral, M. (2000). A pesca com arte de xávega. Relatorios Científicos e Técnicos Instituto de Investigacão das Pescas Mar, 48, pp 32.

Maynou, F., del Gil, M.Mar, Vitale, S., Giusto, G., Foutsi, A., Range, M., et al. (2017). Fishers' perceptions of the European Union discards ban : perspective from south European fisheries. Marine Policy, 89, 147-153.

Morato, T., Machete, M., Kitchingman, A., Tempera, F., Lai, S., Menezes G., et al. (2008). Abundance and distribution of seamounts in the Azores. Marine Ecology Progress Series, $357,17-21$.

Palialexis, A., \& Vassilopoulou, V. (2012a). Metier identification in trammel net fisheries in Greece. Oral paper presented at the 10th Panhellenic Symposium of Oceanography and Fisheries, Athens.

Palialexis, A., \& Vassilopoulou V. (2012b). The local character of trammel net fisheries in Greece and the need of regional spatial approach for management effectiveness. Oral paper presented at the 6th World Fisheries Congress, Edinburgh 7-11th May 2012.

Pham, C., Canha, A., Diogo, H., Pereira, J., Prieto, R., Morato, T. 2013. Total marine fishery catches for the Azores (1950-2010). ICES Journal of Marine Sciences, 70, 564-577.

Pita, C., Dickey, H., Pierce, G., Mente, E., Theodossiou, I. (2010). Willingness for mobility amongst European fishermen. Journal of Rural Studies, 26, 308-319.

Silva, H., \& Pinho, M. (2007). Exploitation, management and conservation: small-scale fishing on seamounts. In T. J. Pitcher, T. Morato, P. J. B. Hart, M.R. Clark, N. Haggan, R. S. Santos (Eds.), Seamounts: ecology, fisheries \& conservation (pp. 333-399). Oxford: Blackwell Publishing.

STECF [Scientific, Technical and Economic Committee for Fisheries]. (2016). The 2016 annual economic report on the EU fishing fleet. (STECF-16-11). 2016. Publications Office of the European Union, Luxembourg, pp 470.

Stergiou, K., Moutopoulos, D., Erzini, K. (2002). Gill net and longlines fisheries in Cyclades waters (Aegean Sea): species composition and gear competition. Fisheries Research, 57, $25-37$.

Stergiou, K., Moutopoulos, D., Casal, H., Erzini K. (2007). Trophic signatures of small-scale fishing gears: implications for conservation and management. Marine Ecology Progress Series, $333,117-128$.

Tsagarakis, K., Palialexis, A., Vassilopoulou, V. (2014). Mediterranean fishery discards: review of the existing knowledge. ICES Journal of Marine Sciences, 71, 1219-1234. 
Tzanatos, E., Somarakis, S., Tserpes, G., Koutsikopoulos C. (2007). Discarding practices in a Mediterranean small-scale fishing fleet (Patraikos Gulf, Greece). Fisheries Management Ecology, 14, 277-285.

Uhlmann, S.S., van Helmond, A.T., Stefánsdóttir, K., Sigurðardóttir, S., Haralabous, J., Bellido, J. M., et al. (2013). Discarded fish in European waters: general patterns and contrasts. ICES Journal of Marine Sciences, 71, 1235-1245.

van Hoof, L., Kraan, M., Visser, N.M., Avoyan, E., Batsleer, J., Trapman, B. (this volume). Muddying the waters of the Landing Obligation: How multi-level governance structures can obscure policy implementation. In S.S. Uhlmann, C. Ulrich, S.J. Kennelly (Eds.), The European Landing Obligation - Reducing discards in complex, multi-species and multi-jurisdictional fisheries. Cham: Springer.

Vassilopoulou, V., Anastasopoulou, K., Haralambous, C., Christides, G., Glykokokkalos, S., et al. (2007). Preliminary results of monitoring discards by coastal fishery vessels in Greek waters. Oral paper presented at the 13th Panhellenic Symposium of Ichthyologists, Mytilene, Greece, Proceedings: $109-116$.

Veiga, P., Pita, C., Rangel, M., Gonçalves, J.M., Campos, A., Fernandes, P., et al. (2016). The EU landing obligation and European small-scale fisheries: what are the odds for success? Marine Policy, 64, 64-71.

Villasante, S. (2012). The management of the blue whiting fishery as complex social- ecologic system: the Galician case. Marine Policy, 36(3), 1301-1308.

Villasante, S., Pazos Guimeráns, C., Garcia Rodrigues, J., Antelo, M., Rivero Rodríguez, S., Da Rocha, J.M., et al. (2015a). Small-scale fisheries and the zero-discard target(p. 73). Brussels: European Parliament, Directorate-General for Internal Policies Policy Department B: Structural and Cohesion Policies.

Villasante, S., Macho, G., Isusi De Rivero, J., Divovich, E., Zylich, K., Zeller, D., et al. (2015b). Estimates of total fisheries removals from the Northwest of Spain (1950-2010). Working Paper Series \#51, University of British Columbia, Canada, pp 18.

Villasante, S., Pita, C., Pazos Guimeráns, C., Rodrigues, J., Antelo, M., Rivero Rodríguez, et al. (2016a). To land or not to land: How stakeholders perceive the zero-discard policy in European small-scale fisheries? Marine Policy, 71, 166-174.

Villasante, S., Pierce, G., Pita, C., Pazos Guimeráns, C., Rodrigues, J., Antelo, M., et al. (2016b). Fishers' perceptions about the EU discards policy and its economic impact on small-scale fishers in Galicia (North West Spain). Ecological Economics, 130, 130-138.

Villasante, S., Macho, G., Isusi de Rivero, J., Divovich, E., Zylich, K., Zeller, D., et al. (2016c). Spain (North West). In D. Pauly, \& D. Zeller (Eds.), Global Atlas of marine fisheries: a critical appraisal of catches and ecosystem impacts (p. 397), Washington, DC: Island Press.

Open Access This chapter is licensed under the terms of the Creative Commons Attribution 4.0 International License (http://creativecommons.org/licenses/by/4.0/), which permits use, sharing, adaptation, distribution and reproduction in any medium or format, as long as you give appropriate credit to the original author(s) and the source, provide a link to the Creative Commons license and indicate if changes were made.

The images or other third party material in this chapter are included in the chapter's Creative Commons license, unless indicated otherwise in a credit line to the material. If material is not included in the chapter's Creative Commons license and your intended use is not permitted by statutory regulation or exceeds the permitted use, you will need to obtain permission directly from the copyright holder.

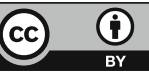

